\title{
RELATIONSHIP BETWEEN TERRORISM AND MACROECONOMIC VARIABLES: ESPECIALLY IMPORT OF CRUDE OIL AND NATURAL GAS IN TURKEY*
}

\author{
Betül YÜCE DURAL ${ }^{1}$, S M Rashed JAHANGIR ${ }^{2}$
}

\begin{abstract}
The main purpose of this study is to observe the interaction between terrorism and energy - crude oil and natural gas import - in Turkey. It also observes the linkage between terrorism and other macroeconomic variables: exchange rate, gross domestic product, foreign direct investment, interest rate and inflation rate. Here, the study considers a time series data of macroeconomic variables' growth rate which is calculated by using natural log formula. Besides, it runs correlation and scatterplot to find out the connection between variables using terrorism as an independent and macroeconomic factors as dependent variables. The study result shows that terrorism is positively correlated with the import of crude oil and natural gas though it is statistically insignificant. In addition, it also demonstrates the correlation between terrorism and other macroeconomic variables. Needless to say, these results will help the foreign and domestic investors to get an idea about the relationship between terrorism and macroeconomic variables in Turkey during 2003 to 2015. However, it is noticeable that consideration of refugee crisis and neighbor countries' political instability could have changed the findings of the study.
\end{abstract} growth.

Keywords: Terrorism, Global Terrorism Index (GTI), Turkey's economic

\footnotetext{
*Bu makale, 26-27 Kasım 2016 tarihlerinde İstanbul'da gerçekleştirilen ICOMEP'16 (International Congress of Management, EconomyandPolicy) Kongresinde bildiri olarak sunulmuş, son gelişmeler ışığında güncellenerek değiştirilmiş ve yeniden yazılmıştır.
}

${ }^{1}$ Yrd.Doç.Dr.,Anadolu Üniversitesi, İktisadi ve İdari Bilimler Fakültesi, İktisat Bölümü, Kalkınma ve Uluslararası iktisat Anabilim Dalı, byuce(at)anadolu.edu.tr

${ }^{2}$ Yüksek Lisans Öğrencisi, Anadolu Üniversitesi, Sosyal Bilimler Enstitüsü, Uluslararası İşletmecilik Yüksek Lisans Programı, rashed582(at)anadolu.edu.tr 


\title{
TERÖRIZM VE MAKRO EKONOMIK DEĞiŞKENLER ARASINDAKI İLIŞKI: TÜRKIYE'DE ÖZELLIKLE HAM PETROL ITHALATI VE DOĞAL GAZ ILE ILIŞKisi
}

\author{
$\ddot{0 z z}$
}

\begin{abstract}
$\mathrm{Bu}$ çalışmanın temel amacı, Türkiye'de terörizm ile enerji-ham petrol ve doğal gaz ithalatının etkileşimini gözlemlemektir. Çalışma aynı zamanda terörizm ile diğer makroekonomik değişkenler arasındaki bağlantıyı da gözlemlemeyi amaçlamaktadır: döviz kuru, gayri safi yurtiçi hasıla, doğrudan yabancı yatırım, faiz oranı ve enflasyon oranı. Burada, çalışma, doğal log formülü kullanılarak hesaplanan makroekonomik değişkenlerin büyüme hızının bir zaman serisi verisini değerlendirmektedir. Ayrıca terörizmi bağımsız değişken ve makroekonomik faktörleri bağımlı değişkenler olarak kullanarak ikisi arasındaki bağlantıyı bulmak için korelasyon ve scatterplot kullanmaktadır. Çalışma sonucunda, terörizmin ham petrol ve doğal gaz ithalatıyla pozitif yönde iliş̧kili olduğu, ancak istatistiksel olarak önemsiz olduğu görülmektedir. İlave olarak terörizm ile diğer makroekonomik değişkenler arasındaki korelasyonu da göstermektedir. Şüphesiz bu sonuçlar, yerli ve yabancı yatırımcıların Türkiye'de 2003 ve 2015 yılları arasında terörizm ile makroekonomik değişkenler arasındaki ilişki hakkında fikir sahibi olmalarına yardımcı olacaktır. Ancak mülteci krizinin ve komşu ülkelerin siyasi istikrarsızlığının dikkate alınmasının, araştırmanın bulgularını değiştirmiş-etkilemiş olabileceği farkedilebilir.
\end{abstract}

Anahtar Kelimeler: Terörizm, Küresel Terörizm İndeksi (GTI), Türkiye'nin ekonomik büyümesi.

Yüce Dural, Betül. ve Jahangir, S M Rashed "Relationship Between Terrorism And Macroeconomic Variables: Especially Import Of Crude Oil And Natural Gas in Turkey”. ulakbilge 5. 14 (2017): 1373-1394

Yüce Dural, B. ve Jahangir, S. M. R. (2017). Relationship Between Terrorism And Macroeconomic Variables: Especially Import Of Crude Oil And Natural Gas in Turkey. ulakbilge, 5 (14), s.1373-1394. 


\section{INTRODUCTION}

Terrorism- a horrific panic word which leads to drastic changes in the normal way of life and living standards, be it economic, social, political sense etc. of any society. Although the effects of terrorism are exterminatory in every sector in a society (Waxman, 2011:9), considering the relation of terrorism, this term is more related to political phenomena. According to Merriam - Webster, "Terrorism means the use of violent acts to frighten the people in an area as a way of trying to achieve a politicalgoal." This politica goal is responsible for the instability of important macroeconomic variables which lead to changing the economic condition of a country. On the other hand, the most frequently used definition is a combination of threeelements (i) use of extreme violence (EndersandSendler, 2006), (ii) nature of terrorism acts by individuals and organizations (Nasir et al., 2011), and (iii) publicity (LlussáandTavares, 2007). Therefore, this study analyzed the linkage of terrorism on macroeconomic factors in Turkey - especially import of crude oil and natural gaswhich is important for economic growth.

Now, the important question is: why it is necessary to consider terrorism for Turkey's economy? What are the most vital reasons that motivate researchers to choose the topic? First and foremost, Turkey's geographical position; it is situated at the crossroad of Europe, Asia and Africa as well as is a bridge between East and West. Second, Turkey shares its border with eight countries: Greece, Bulgaria, Azerbaijan, Armenia, Iran, Iraq and Syria which are not just countries in a same region, but different. Turkey is a harbor of Middle Eastern, Caucasian as well as European country. Third, number of ethnicity in Turkey; morethan 31 ethnicgroups in Turkey-different views, languages, cultures - live together, forinstance; Armenians, Kurds and Greeks. Forth, Turkey has been a member and majors trategic partner of the North Atlantic Treaty Organization (NATO) and United Nation (UN) for last 50 years (Yaya, 2009). They have been working with UN and NATO for different peace mission an dmission agains terrorism. Turkey shares it smilitary for all eviating the presence of terrorists in differentcountries-especially Iraq and Syria. According to CIA, Turkey is a key partner in the war against global terrorism. Finally, there are some domestic and regionalterrorist groups such as Kurdish Worker's Party (PKK), Revolutionary People's Liberation Party/Front (DHKP/C), Islamic State of IraqandSyria (ISIS) etc.,whoareresponsibleformajorterroristattacks in Turkey. These attacks some how push Turkey to face a short term as well as long term economic vulnerability. For these reasons, the topic is most important and necessary to analyze not just forTurkey, but for the world.

According to CIA World Factbook, “Turkey's consumption of oil and gas is more than its production capacity. In 2014, Turkey's total liquid fuels consumption 
averaged $712,000 \mathrm{~b} / \mathrm{d}$ where moret han $90 \%$ of total liquid fuels came from imports. Turkey's crude oil imports are expected to double over the next decade. On the other hand, most of Turkey's crude oil imports came from Iraq and Iran with each supplying slightly more than a quarter of the country's crude oil." Now considering natural gas import of Turkey, Russia is the largest supplier, whereas Iran, Azerbaijan, and Algeria also play an important role (International EnergyAgency). Accordingto U.S. Energy Information Administration, “Turkey's imported natural gas is mainly used in the power generation sector, and remaining consumption split evenly between building sector (residential and commercial) and industrial sectors." Now considering 2015 data, according toTurkey's Ministry of Foreign Affairs, Turkey imports oil and natural gas around $89 \%$ and $99 \%$ respectively where 25 million tons of crude oil and around $48.4 \mathrm{bcm}$ of gas. Here, Iraq is the main supplier for Turkey's crude oil (45.6\%) and rest of the amount from Iran (22.4\%), Russia (12.4\%), Saudi Arabia (9.6\%), Colombia (3.5\%), Kazakhstan (2.6\%) and Nigeria $(2.1 \%)$. On the other hand, Russia is the biggest source of natural gas import. In 2015, Turkey imported $55.3 \%$ of the natural gas from Russia, followed by Iran (16.2\%), Azerbaijan (12.7\%), Algeria (8.1\%) and $2.6 \%$ from Nigeria (BOTAŞ and EMRA) $)^{3}$.

The main goal of this study is to inspect the interaction between terrorism and energy- especially crude oil and natural gas import a long with some important macroeconomic factors: Gross Domestic Product (GDP), Foreign Direct Investment (FDI), Exchange Rate (XR), interest rate, inflation rate of Turkey's economy.

\section{LITERATURE REVIEW}

The crucial point of this study is to investigate the relation between terrorism and energy especially crude oil and natural gas import and some important macroeconomic variables - GDP, FDI, XR, interest rate, inflation rate - of Turkey's economy. There are some studies which have analyzed terrorism and Turkey's economic growth before the economic crisis (2001) and 9/11 World Trade Center attack, but this study accentuates on after crisis and attack which gives a real-time information for getting a clear view of Turkey's economy.

Terrorism may have severe human and economic consequences due to the destruction of physical capital, lost lives, higher levels of uncertainty. Considering macroeconomic variables, terrorism is correlated with macroeconomic variables (Shahbaz, 2013:1). That's why having a clear idea about the macroeconomic variables helps to understand the study precisely. Firstly, Exchange rates - a price of

\footnotetext{
${ }^{3}$ Boru Hatları İle Petrol Taşıma Anonim Şirketi, PetroleumPipelineCompanyandRepublic of TURKEY Energy Market RegulatoryAuthority.
} 
a nation's currency in terms of another currency. Exchange rate (XR) fluctuation or stability determines the quantum and direction of foreign trade and commerce. There is a positive correlation between terrorism and exchange rate. It means that due to the increase of terrorism, exchange rate also increases as the domestic price of foreign currency increases, as consequences currency depreciates (Qaiser et al., 2012: 4). Alongside, Inflation is defined as a sustained increase in the general level of prices for goods and services which is measured as an annual percentage increase. Pursuing sustainability of low inflation reduces the intense of terrorism (Shahbaz, 2013:1). In this study, interest rate-a percentage of principal amounts, by a lender to a borrower for the use of assets which is typically noted on annual basis - plays an important role. Increasing terrorism leads to appreciating interest rate which attracts investors; Central Banks increases interest rate for economic stability (Shahbaz, 2013). Together with these factors, GDP has a crucial relation with terrorism. Gross domestic product (GDP) is the monetary value of all the finished goods and services produced within a country's borders in a specific time period. Increasing terrorism depreciates the GDP growth rate because of less investment which is responsible for less production (Bilgel\&Karahasan, 2015). Furthermore, terrorism has a negative impact on foreign direct investment (FDI) because of declining of investment from foreign investors due to uncertainty (Sandler \& Enders, 2008). Finally, the import of crude oil and natural gas has a negative relation with terrorism because of country's instability which increases the bargaining power of supplier. Normally, terrorism restricts import demand (Estrada, et al., 2015)

There are some studies which have made analysis about terrorism, economic development as well as macroeconomic variables. Among these, a handful studies have focused on the relationship between macroeconomic variables-especially import of crude oil and natural gas - and terrorism.

Araz-Takay, Arin, \&Omay (2009) investigated terrorism and macroeconomic effect actually how much macroeconomic effects on terrorism and vis-a-vis. The study found that the impact of terrorism on the aggregate economy is robust during the expansionary period. On the other hand, it is significant only recessionary period when it examines impact of economic activity on terrorism.

Bilge \&Karahasan (2015) investigated how much economic cost occurs by the terrorism of Kurdistan Worker's Party (PKK). For measuring the cost, the study has considered Eastern and Southeastern provinces of Turkey and applied the synthetic control method. The study found a down tern illustration in economy. After the appearance of terrorism, the per capita real GDP declined by 6.6 percent in 
Eastern and Southeastern Anatolia compare to synthetic Eastern and Southeastern Anatolia without terrorism.

Drakos\&Kutan (2003) analyzed the regional effects of terrorism on tourism and the study considered there Mediterranean countries-Greece, Israel and Turkey. For conducting the study they developed a consumer-choice theoretical model to test how terrorism effects market share of competitors' in tourism sector. The result shows a significant cognation effect of terrorism on tourism sector.

Harberger (2003) studied the impact of economic growth on real exchange rate especially the reasons of fluctuation of real exchange rate. The study found that there is no systematic connection between economic growth and real exchange rate.

Kemal \&Qadir (2005) analyzed the long-run relationship and the short-run dynamics among the three variables. The study found a long run relationship among real exchange rate, imports and exports - real exchange rate negatively related to exports and positively with imports. Although, it is noticeable that sudden movement of real exchange rate has not affect on exports.

Öcal\&Yildirim (2010) analyzed what effects terrorism has on economic growth and here he considered provinces of Turkey for the time period 1987 to 2001. The study considered a traditional global regression analysis where geographically weighted regression (GWR) is used for examining spatial variations in the relationships to obtain locally different parameter estimates. The results of GWR show its provincial effects are less pronounced for the Western provinces compared to the Eastern and South Eastern provinces.

Shaffer (2005) analyzed Turkey's energy policies and the political and economic opportunities and challenges created for Ankara under tight international energy market conditions. The study shows the insight of Turkey's decision on energy policies; natural gas pipeline, nuclear plants etc.

(Shahbaz, 2013) analyzed linkages between inflation, economic growth and terrorism in Pakistan. The study considers annual frequently data over the period of 1971 to 2010. To establish the robustness of long run relationship the study applied a rolling window approach, in the meantime the ARDL bounds testing approach to co-integration has been applied. The results show that low inflation can reduce terrorism as well as increasing terrorism activities crowding out some of the benefits of economic growth. 
Simon (1997) found that exchange rate and current account have direct and positive relationship with inflation and both exchange rate and current account are the key factors that immensely affect the small economies.

Yaya (2009) examined how tourism is affected by terrorism in Turkey and this study conducted a time series methods- - "transfer function". The results indicate a negative which is a minor impact of terrorism because it is observed within approximately one year.

Yuan \&Guo (2013) studied that both GDP and exchange rate have a remarkable influence on the size of foreign exchange reserves and the effect of exchange rate on foreign exchange reserve is higher than GDP at mean place and middle and lower quantile, smaller than GDP at higher quantile.

\section{HYPOTHESIS}

$\mathrm{H}_{0}=$ Assumes there is no correlation between terrorism and macroeconomic factors.

$\mathrm{H}_{1}=$ Terrorism has negative correlation with import of crude oil.

$\mathrm{H}_{2}=$ Terrorism leads to decreasing import of natural gas.

$\mathrm{H}_{3}=$ Terrorism depreciates exchange rate.

$\mathrm{H}_{4}=$ Terrorism is responsible for declining GDP growth rate

$\mathrm{H}_{5}=$ Terrorism diverting foreign direct investment.

$\mathrm{H}_{6}=$ Terrorism appreciates interest rate.

$\mathrm{H}_{7}=$ Terrorism is responsible increasing inflation rate.

\section{METHODOLOGY}

Thirteen years secondary annual data (2003 to 2015) has been taken where terrorism-represented by Global Terrorism Index (GTI) score growth rate-is considered as an independent and growth rate of import of crude oil, import of natural gas, exchange rate, gross domestic product, foreign direct investment, interest rate and inflation rate as dependent variables. The data collected from World Bank data, International Energy Agency and Institute for Economics \& Peace. 
Alongside, for calculating growth rate, the study considers the natural log formula of ending value at year $t$ by the ending value of the previous year. Finally, SPSS (version 16.0) has been used for statistical analysis - correlation and scatterplot.

\section{FINDINGS AND ANALYSIS}

Economically and geopolitically Turkey plays an important role which bridges Europe and Asia where most of the business transactions and geo-culture take place by the way of Silk Road (Arslan. R). For that reason, any type of unrestinternational or domestic - in Turkey affects the international market exceedingly. So, increasing terrorism in Turkey affects not only Turkey's economy itself but also the world economy significantly. This study analyzed the relation of Terrorism with Turkey's economy by in two ways where descriptive analysis gives a general idea and statistical analysis represents statistical synopsis.

\subsection{Descriptive Analysis}

For descriptive analysis Table-1 summarizes the Global Terrorism Index (GTI) indicators during the period from 2003 to 2015 in Turkey.

Table-1: Global Terrorism Index (GTI) indicators from 2003 to 2015 in Turkey.

\begin{tabular}{lllll}
\hline Year & Incidents & Fatalities & Injuries & Property \\
\hline $\mathbf{2 0 0 3}$ & 17 & 63 & 777 & 08 \\
$\mathbf{2 0 0 4}$ & 24 & 19 & 90 & 10 \\
$\mathbf{2 0 0 5}$ & 35 & 27 & 113 & 13 \\
$\mathbf{2 0 0 6}$ & 36 & 34 & 305 & 12 \\
$\mathbf{2 0 0 7}$ & 25 & 20 & 112 & 05 \\
$\mathbf{2 0 0 8}$ & 28 & 42 & 274 & 06 \\
$\mathbf{2 0 0 9}$ & 13 & 18 & 48 & 05 \\
$\mathbf{2 0 1 0}$ & 19 & 12 & 7 & 11 \\
$\mathbf{2 0 1 1}$ & 50 & 25 & 105 & 22 \\
$\mathbf{2 0 1 2}$ & 130 & 100 & 276 & 48 \\
\hline
\end{tabular}




\begin{tabular}{lllll}
\hline $\mathbf{2 0 1 3}$ & 34 & 57 & 162 & 18 \\
$\mathbf{2 0 1 4}$ & 68 & 20 & 52 & 31 \\
$\mathbf{2 0 1 5}$ & 308 & 337 & 827 & 101 \\
\hline
\end{tabular}

Source: Institute for Economics \& Peace, Vision of Humanity.

The table gives an explanation of Global Terrorism Index (GTI) indicators. The first indicator, "incidents", indicates the total number of terrorist attacks in a given year where the low of 17 attacks was recorded in 2003 with the peak being at 308 in 2015. On the other hand, "fatalities", indicates a total number of fatalities due to terrorist attacks in a given year where the high of 337 fatalities was experienced in the same year but that was less in the previous year. Now, considering "injuries" which indicates a total number of injuries due to terrorist attacks in a given year where the number of massive injuries was 777 in 2003 which generally oscillated in a decreasing manner in the next years. But it is noticeable that during 2010 the injuries were at a record low of 7 which was the smallest considering rest of the years. Though in 2015, the number of injuries increased dramatically (827) which was the maximum number over thirteen years. Finally, "property": total property damage due to terrorist attacks in a given year, it was high in 2015 (101 damages) like other indicators.

Table-2: Macroeconomic variables growth rate from 2003 to 2015 in Turkey.

\begin{tabular}{llllllll}
\hline Year & $\begin{array}{l}\text { Crude oil } \\
\text { (Import) }\end{array}$ & $\begin{array}{l}\text { Natural } \\
\text { gas } \\
\text { (Import) }\end{array}$ & $\begin{array}{l}\text { Exchange } \\
\text { rate }\end{array}$ & GDP & FDI & $\begin{array}{l}\text { Interest } \\
\text { rate }\end{array}$ & $\begin{array}{l}\text { Inflation } \\
\text { rate }\end{array}$ \\
\hline $\mathbf{2 0 0 3}$ & 1.81 & 18.66 & -0.42 & 26.47 & 45.30 & -43.08 & -57.52 \\
$\mathbf{2 0 0 4}$ & -0.74 & 4.75 & -5.15 & 25.79 & 49.24 & -36.77 & -87.13 \\
$\mathbf{2 0 0 5}$ & -2.24 & 19.99 & -5.92 & 20.83 & 128.14 & -28.77 & -4.30 \\
$\mathbf{2 0 0 6}$ & 2.84 & 12.89 & 6.13 & 9.46 & 69.93 & 25.95 & -5.49 \\
$\mathbf{2 0 0 7}$ & -2.60 & 16.83 & -9.20 & 19.80 & 8.82 & -10.54 & -9.17 \\
$\mathbf{2 0 0 8}$ & -7.62 & 2.71 & -0.11 & 12.09 & -10.49 & -4.88 & 17.63 \\
$\mathbf{2 0 0 9}$ & & & & - & & & \\
& -42.39 & -3.62 & 17.47 & 17.26 & -83.82 & -83.62 & -51.33 \\
\hline
\end{tabular}




\begin{tabular}{llllllll}
\hline $\mathbf{2 0 1 0}$ & 17.59 & 5.97 & -3.09 & 17.37 & 5.81 & 7.41 & 31.51 \\
$\mathbf{2 0 1 1}$ & 6.50 & 14.21 & 10.84 & 5.79 & 57.57 & -19.67 & -28.04 \\
$\mathbf{2 0 1 2}$ & 7.43 & 4.56 & 6.98 & 1.80 & -19.73 & -4.45 & 31.76 \\
$\mathbf{2 0 1 3}$ & -4.90 & -1.43 & 5.83 & 4.27 & -7.02 & -20.07 & -17.11 \\
$\mathbf{2 0 1 4}$ & -5.97 & 8.45 & 13.94 & -3.01 & 1.12 & 60.61 & 16.70 \\
$\mathbf{2 0 1 5}$ & & & & - & & & \\
& 36.05 & -2.11 & 21.74 & 10.63 & 29.49 & -9.53 & -14.35 \\
\hline
\end{tabular}

Source: International Energy Agency, World Bank data.

The table gives us an overview of macroeconomic variables growth rate. In 2003 , there was a negative growth rate of exchange rate ${ }^{4}$ but it turned to positive (6.13) in 2006 and peaked in 2009 then slipped but again started going up and reached highest point in 2015 (21.74). On the other hand, GDP did not experience negative fluctuations up to 2008 but in the next year Turkey faced a large negative growth rate $(-17.26)$ which was recovered next years, but again it experienced negative growth rate in 2014 and 2015. Likewise, considering foreign direct investment (FDI), since 2003, it experienced positive growth dramatically which peaked (128.14) in 2005. Immediately after 2005, it started to go down and experienced a negative growth rate in the next years with two comparatively large positive growth rates in 2011 and 2015. Now focusing on other two macroeconomic variables; interest rate and inflation rate, which also experienced negative growth rate during the year, but it bounced back by 60.61 and 16.70 respectively in 2014, though there was a dramatic negative growth rate in 2003 and 2009.

Apparently, based on figure-1, the growth rate of crude oil and natural gas import show divergent tendency in 2015 though previous years crude oil experienced a negative growth rate. Actually, considering 2010 growth rate, the import of natural gas increased more than the import of crude oil. Most importantly, import of crude oil plummeted in 2009 which is the lowest negative growth rate during 2003 to 2015.

\footnotetext{
${ }^{4}$ Exchange Rate growth rate: Usedtorefertoappreciationordepreciation of theTurkish lira againstthe USD wherenegativegrowth rate meanstheTurkish lira gainedagainstthe USD withtheoppositebeingequallytrue.
} 


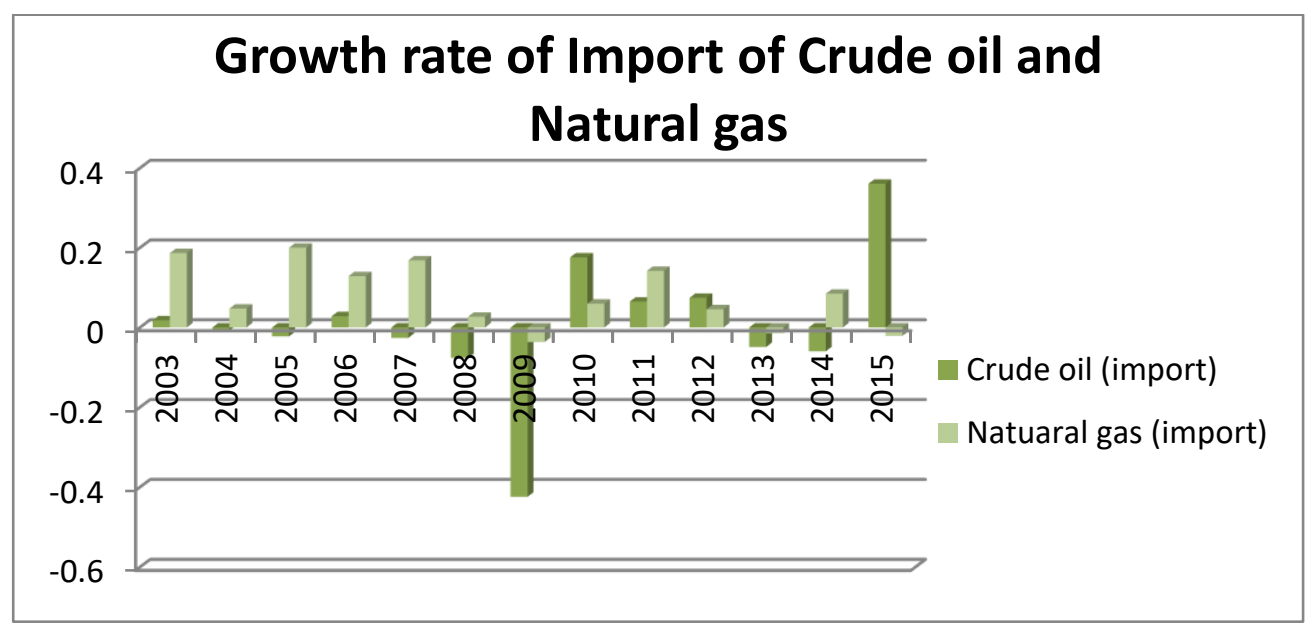

Figure-1: Growth rate of crude oil and natural gas import from 2003 to 2015 in Turkey.

Now, the figure- 2 shows a trend of crude oil import, GTI, and natural gas import from 2003 to 2015 in Turkey where blue line represents natural gas import, red signifies GTI and the green line indicates the crude oil import. The graph starts with a downward trend where falling growth rate of crude oil and natural gas lie with the declining of GTI, but later there was a development for two factors-crude oil and GTI - till 2006 but the demand for natural gas fluctuated during that period. It is noticeable that, after 2008, the demand for crude oil plummeted where GTI and natural gas import declined slightly. But, next year, surprisingly, import of crude oil growth reached the highest point. After 2010, three factors faced a normal trend up to 2013. But later years blue line means natural gas import showed a contrary trend with GTI and crude oil import. 


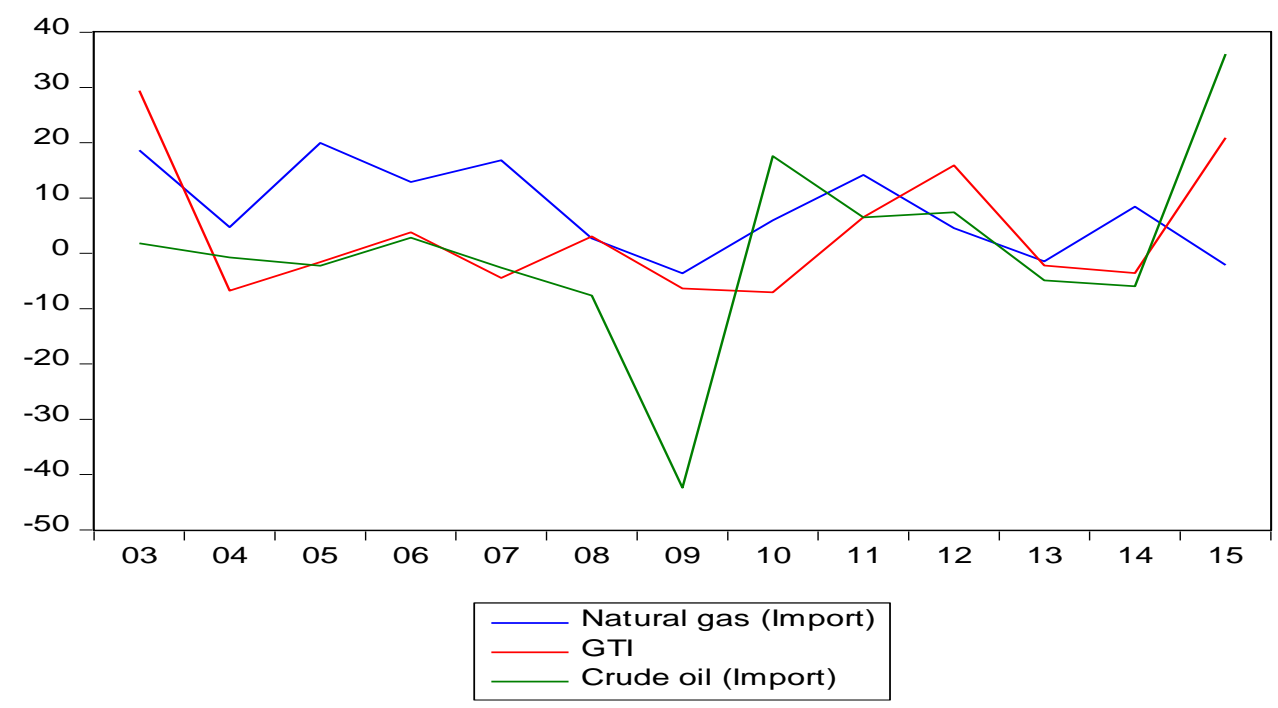

Figure-2: Growth rate of Crude oil Import, GTI and Natural Gas Import Trends from 2003 to 2015 in Turkey.

\subsection{Statistical Analysis}

\subsubsection{Correlation}

Statistical analysis has been applied considering macroeconomic variables such as import of crude oil, import of natural gas, exchange rate, GDP, FDI, interest rate and inflation rate based on GTI score. Table-3 shows the correlation between GTI score (terrorism) and macroeconomic variables. 
Table-3: Correlation between GTI score and macroeconomic variables in Turkey.

\begin{tabular}{|c|c|c|c|c|c|c|c|c|}
\hline Variables $^{5}$ & $\begin{array}{l}\text { GTI } \\
\text { score }\end{array}$ & XR & GDP & FDI & $\begin{array}{l}\text { Interest } \\
\text { rate }\end{array}$ & $\begin{array}{l}\text { Inflation } \\
\text { rate }\end{array}$ & $\begin{array}{l}\text { CO } \\
\text { Import }\end{array}$ & $\begin{array}{l}\text { NG } \\
\text { Import }\end{array}$ \\
\hline GTI score & 1 & & & & & & & \\
\hline XR & 0.273 & 1 & & & & & & \\
\hline GDP & -0.013 & $-0.917 * *$ & 1 & & & & & \\
\hline FDI & 0.162 & -0.390 & $0.590 *$ & 1 & & & & \\
\hline Interest rate & -0.067 & 0.047 & 0.004 & 0.178 & 1 & & & \\
\hline Inflation rate & -0.055 & 0.023 & -0.170 & -0.109 & $0.668^{*}$ & 1 & & \\
\hline CO (import) & 0.465 & 0.016 & 0.182 & 0.452 & 0.434 & 0.293 & 1 & \\
\hline NG (Import) & 0.150 & $-0.564 *$ & $0.672 *$ & $0.710 * *$ & 0.153 & -0.014 & 0.106 & 1 \\
\hline
\end{tabular}

*Correlation is significant at the 0.05 level (2-tailed)

** Correlation is significant at the 0.01 level (2-tailed)

Here, the correlation between GTI score and exchange rate is low positive (0.273) whereas a very low positive correlation exists between terrorism and FDI (0.162). On the other hand, GDP, interest rate and inflation is negatively correlated with GTI score. Finally, import of crude oil (0.465) and natural gas (0.150) are positively correlated with terrorism. But, based on intensity, crude oil import is more positively correlated with terrorism rather than natural gas import.

\subsubsection{Scatterplot}

Scatterplot - also called scatter diagram, scatter chart, scatter gram, or scatter graph - a graphical representation of a relationship between two variables. It is illustrated by two axes: horizontal axis (x-axis) and vertical axis (y-axis). Most of the cases scatterplot remains a line of best fit which signifies the trend of the data. If the line of the best fit shows an upward trend then there is a positive correlation, otherwise, it is negative when it shows a downward trend. But if the line of the best

${ }^{5} \mathrm{XR}=$ Exchange Rate, GDP= GrossDomestic Product, FDI= Foreign Direct Investment, $\mathrm{CO}=$ CrudeOil, $\mathrm{NG}=$ Natural Gas 
fit is horizontal or vertical, or it is not possible to draw a line of best fit then there is little or no correlation. Actually, scatter plot shows a visual representation of the correlation (Williams).

\section{Terrorism and Exchange rate}

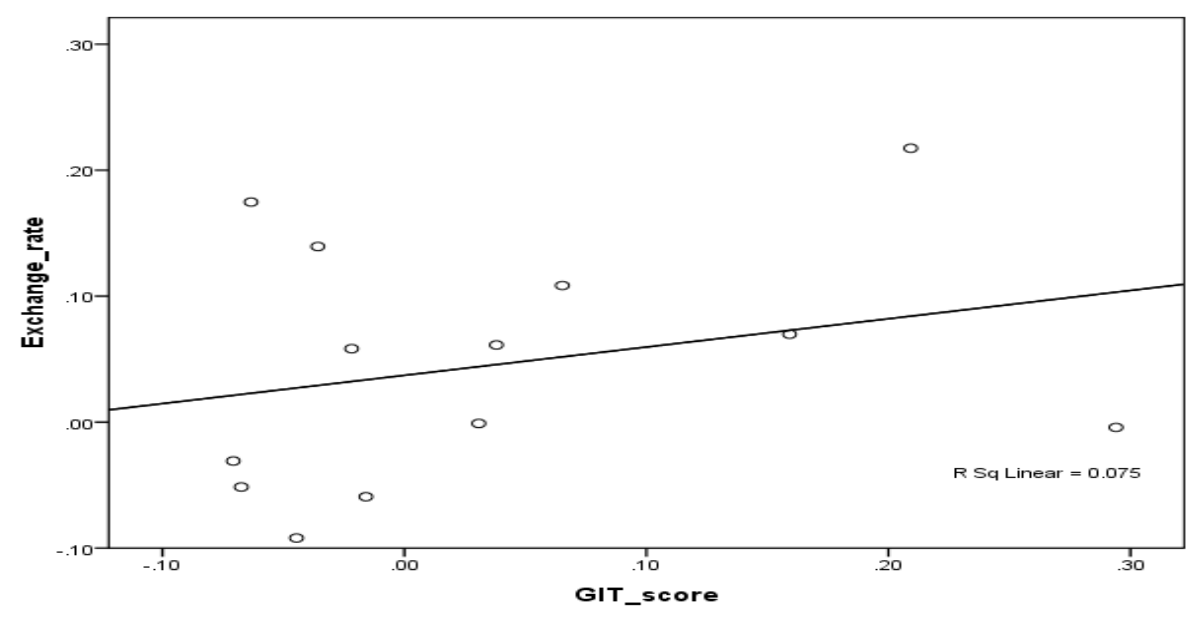

Figure-3: Terrorism and exchange rate

The figure-3 illustrates a slight upward slope. So, a low positive correlation exists between terrorism (GTI score) and exchange rate. It signifies that as terrorism increases, the value of exchange rate increases, but considering the behavior of exchange rate increasing value means depreciating its value. The scatter plot also shows R-square value. Here, the value of $\mathrm{R}$ square is 0.075 which represents that only $7.5 \%$ variation of exchange rate fluctuation is explained by the terrorism. 
Terrorism and Gross Domestic Product (GDP)

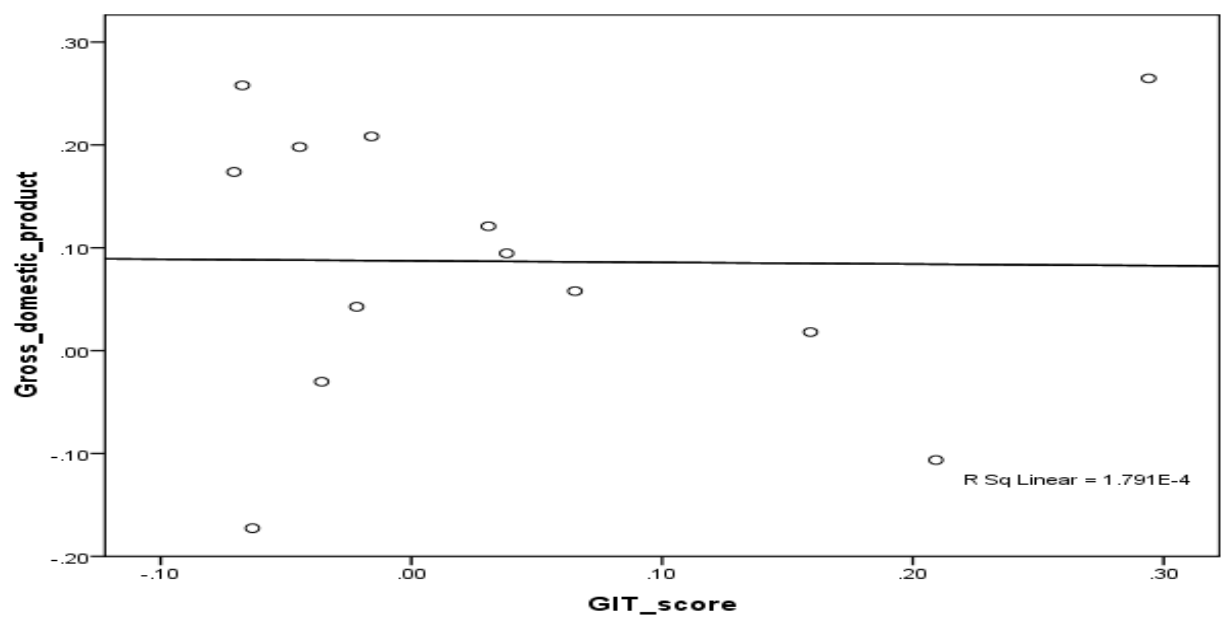

Figure-4: Terrorism and GDP

The figure-4 shows a straight horizontal line of best fit which represents a little or no correlation between terrorism and gross domestic product. So, increasing terrorism does not explain the gross domestic product; this is explicit because of the value of $\mathrm{R}$ square which is nearly zero. 
Terrorism and Foreign Direct Investment (FDI)

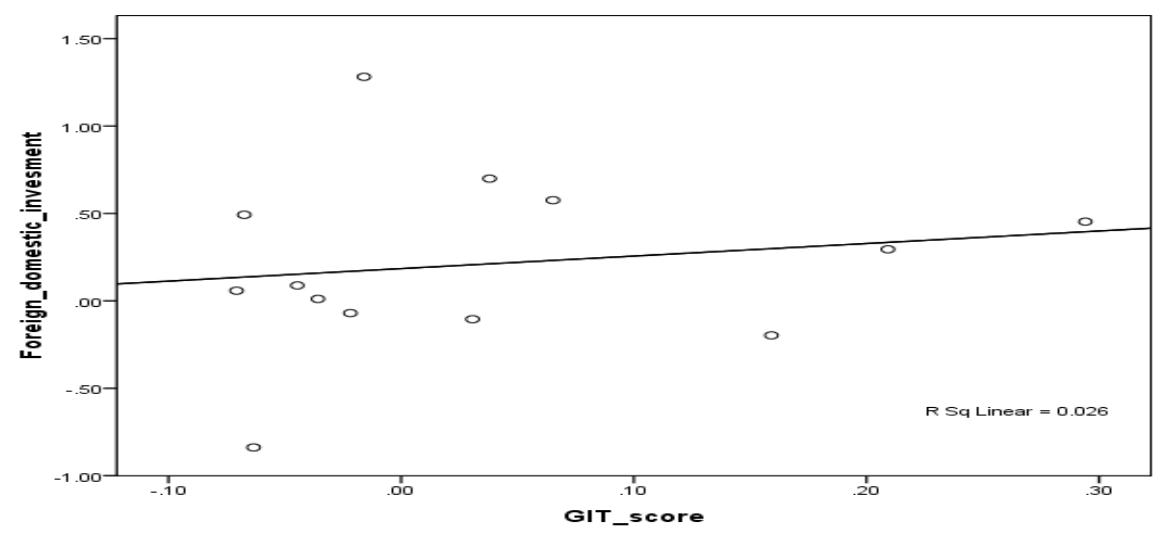

Figure-5: Terrorism and FDI

The figure-5 illustrates a slight upward slope means a low positive correlation between terrorism and foreign direct investment. It represents that increasing terrorism leads to raising foreign direct investment. The value of $\mathrm{R}$ square is 0.026 which is very little; only $2.6 \%$ variation of FDI is explained by terrorism.

Terrorism and Interest rate

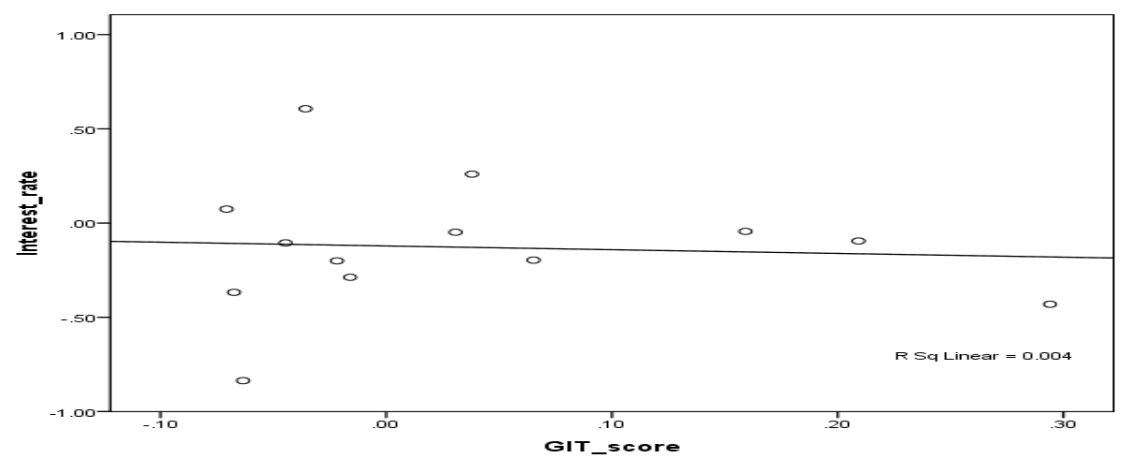

Figure-6: Terrorism and interest rate 
The figure- 6 demonstrates a downward slope of the line of best fit. There is a low negative correlation exist between terrorism and interest, and it is more clear because of the R-square value. Now, considering R-square value, it is difficult to explain how much these two variables relate each other because the value is nearly zero.

\section{Terrorism and Inflation}

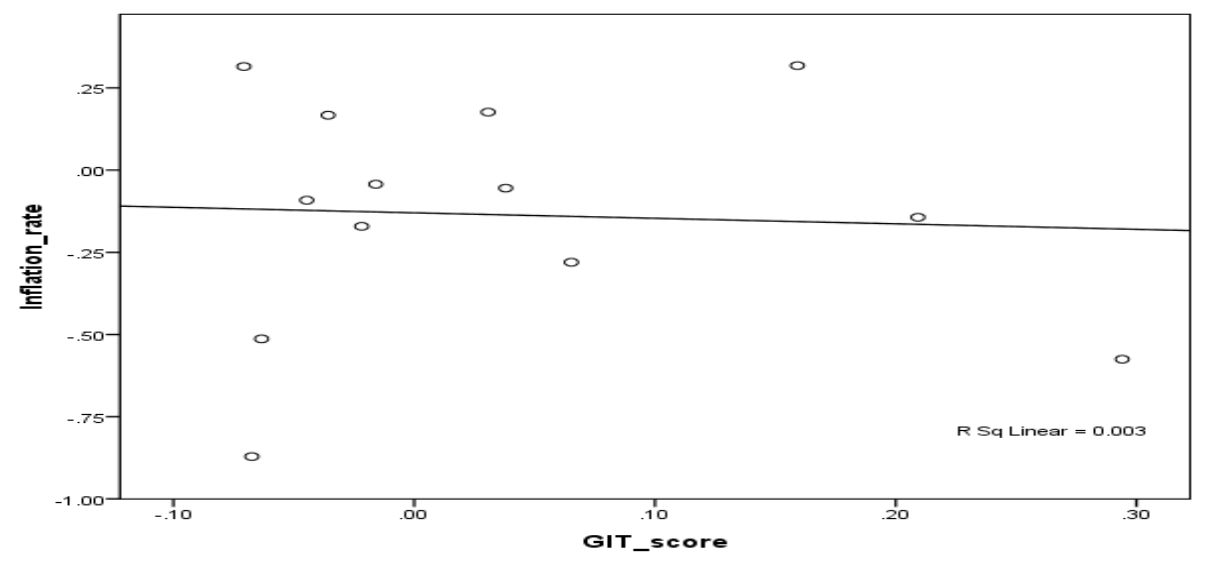

Figure-7: Terrorism and inflation

The figure-7 illustrates a downward slope of the line of best fit. There is a low negative correlation exists between terrorism and inflation. Therefore, increasing terrorism leads to decreasing inflation. On the other hand, the value of $\mathrm{R}$ square is 0003 means only $0.03 \%$ variation of inflation is explained by terrorism. 
Terrorism and import of crude oil

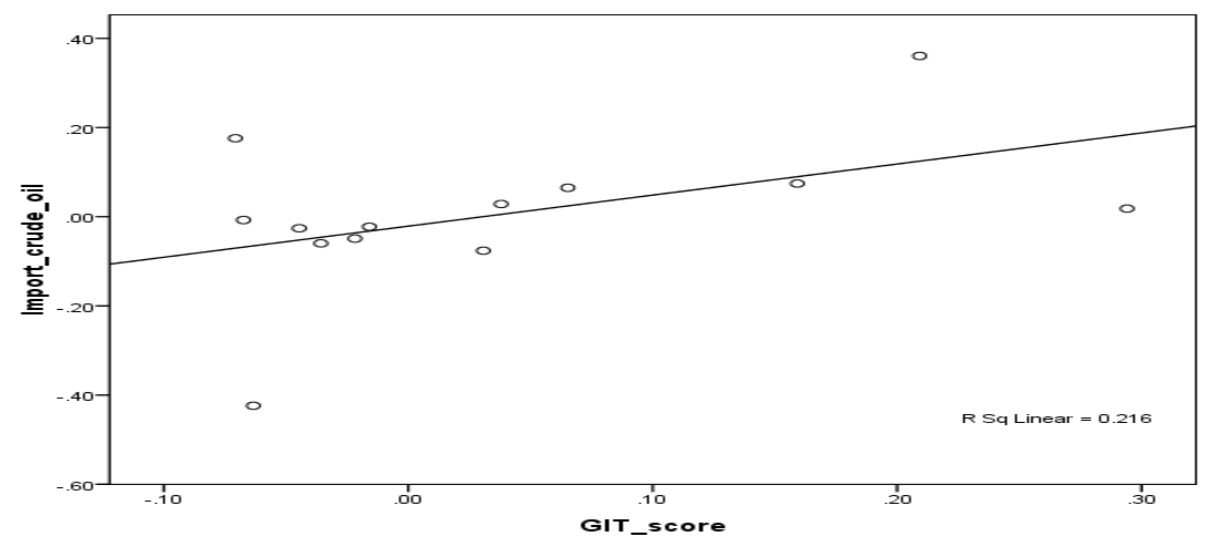

Figure-7: Terrorism and import of crude oil

Considering the other variables, the figure- 8 illustrates a strong positive correlation between terrorism and import of crude oil. It shows an upward line of best fit slope; it means that as terrorism increases, the amount of import of crude oil also increases. Here, the $\mathrm{R}$ square value is more than any other variables. The value shows that $21.6 \%$ variation of import of crude oil is explained by the terrorism.

Terrorism and import of natural gas

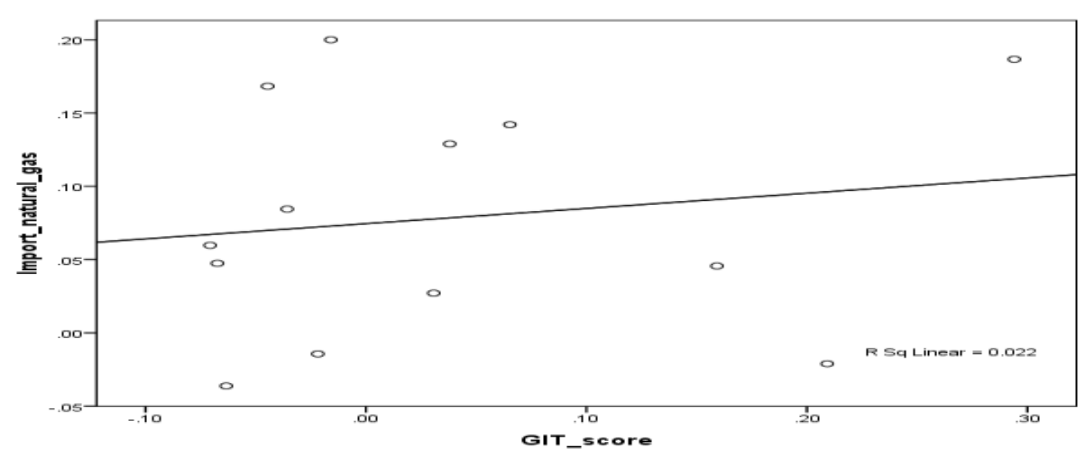

Figure-8: Terrorism and import of natural gas 
The figure- 8 represents an upward slope of the line of best fit which simplifies that terrorism and import of natural gas are positively correlated with each other-as terrorism increases, import of natural gas also increases. Here, the $\mathrm{R}$ square value is 0.022 means only $2.2 \%$ variation of import of natural gas is explained by terrorism.

\section{CONCLUSION AND RECOMMENDATION}

Terrorism is a crucial factor for the economy because of its relation to the macroeconomic factors. The study has analyzed the relationship between terrorism (GTI score) and macroeconomic variables: exchange rate, GDP, FDI, interest rate, inflation rate and import of crude oil and natural gas in Turkey's economy from 2003 to 2015. Although there are some other studies which analyzed Turkey's economic situation based on macroeconomic variable as well as terrorism, the specificity of this study is to analyze the connection of terrorism with macroeconomic factors - especially import of crude oil and natural gas - after the grave economic crisis (2001) which differentiate this study from others.

Now considering the relationship, the macroeconomic variables are linked with terrorism although the intensity is less in terms of some macroeconomic variables but indeed there is a linkage between terrorism and economic activity. Taking Consideration of hypotheses, the study failed to reject the null hypothesis $\left(\mathrm{H}_{0}\right)$ because it is statistically insignificant at 5\% level of significance, though there is a correlation between terrorism and macroeconomic variables. Furthermore, it is noticeable that, normally, increasing terrorism decreases import of crude oil and natural gas (Estrada, et al., 2015), but, here, a positive correlation exist between them, means rising terrorism increases import of crude oil and natural gas in Turkey. Actually it is a good sign for Turkey's economy but, on the other hand, it creates a dispute about their economic policies which generates a platform for questioning. However, two important considerations can detour the dispute: (i) strong economic policies and (ii) nominal contribution of oil and gas in the economy.

In this challenging situation, for precaution, Turkey can concentrate on alternatives energy sources which will help to stabilize Turkey's economic growth in future. Actually, for both sectors - crude oil and natural gas- they can accentuate on some points. Firstly, creating portfolios by negotiating with more suppliers in both sectors can reduce the bargaining power of supplier. Secondly, focusing on new alternatives means investing more on innovation in energy sectors which will help to minimize the dependency on oil and gas. Thirdly, arranging an effective negotiation environment with "Terrorist Groups" (by the Secretary of State, USA) - Kurdistan 
Worker's Party, Islamic State of Iraq, and the Levant etc. would alleviate terroristic events, and that will help to stabilize both sectors (crude oil and natural gas). Finally, Turkey can increase awareness among people about the benefits (economic and environmental) of solar system, wind turbine, biogas etc. which will make a diversion in the energy sector as well as minimize the dependency on oil and gas too.

Now considering limitations, there are some factors which might have altered the findings of the study. First, refugee crisis has an intensive impact on Turkey's economy which is an important factor for the economy (Srivastava, 2016). But, it is noticeable that this study did not consider the refugee crisis. In addition, the political instability in neighbor countries (Syria, Iraq) has not been considered, too. Finally, the 2016 GTI data which has not been published yet, that would have given a realtime synopsis about the current economic growth in Turkey.

In conclusion, there is a relationship between terrorism and Turkey's economic growth from 2003 to 2015, but statistically it is not significant. Nevertheless, Turkey can take an intensive observation on terrorism which will accelerate economic stability.

\section{REFERENCES}

Araz-Takay, B., Arin, K. P., \&Omay, T. (2009). The endogenous and non-linear relationship between terrorism and economic performance: Turkish evidence. Defence and Peace Economics, 20(1), 1-10.

Arslan. R. Turkey's Geopolitical and geostrategical importance for the EU. Retrieved from: https://www.academia.edu/10933527/Turkeys_Geopolitical_and_geostrategical_importance_f or_the_EU

Bilgel, F., \&Karahasan, B. C. (2015). The Economic Costs of Separatist Terrorism in Turkey. Journal of Conflict Resolution, 0022002715576572

Drakos, K., \& Kutan, A. M. (2003). Regional effects of terrorism on tourism in three Mediterranean countries. Journal of Conflict Resolution, 47(5), 621-641. 
Estrada, et al. (2015). The economic impact of terrorism: A new model and its application to Pakistan. Journal of Policy Modeling, 37 (2015) 1065-1080.

Harberger, A. (2004). "Economic Adjustment and the Real Exchange Rate", in S. Edwards and L.Ahamed (eds.), "Economic Adjustment Exchange Rates in Developing Countries", University of Chicago Press, 10, 308-321.

Husain, A.M., Mody, A., Rogoff, K.S. (2004). "Exchange Rate Regime Durability and Performance in Developing Versus Advanced Economies", Journal of Monetary Economics, 52(1), 35-64.

Kemal, M.A. \&Qadir, U. (2005). Real Exchange Rate, Exports, and Imports Movements: A Trivariate Analysis. The Pakistan Development Review 44: 2 (Summer 2005) pp. 177-195.

Mirchandani, A. (2013). Analysis of Macroeconomic Determinants of Exchange Rate Volatility in India. International Journal of Economics and Financial Issues. Vol. 3, No. 1, 2013, pp.172-179.

Obstfeld, M., Melitz, M.J. \& Krugman, P. (2014). International Finance: Theory and Policy (10 edition). London-Pearson.

Öcal, N., \&Yildirim, J. (2010). Regional effects of terrorism on economic growth in Turkey: A geographically weighted regression approach. Journal of Peace Research.

Qaiser, I., Sohail, N., Liaqat, M., \&Mumtaz, A. Impact of Terrorism on Forex Market and Karachi Stock Exchange: Evidence from Pakistan.

Ramasamy, R. \& Abar, S.K. (2015). Influence of Macroeconomic Variables on Exchange Rates. Journal of Economics, Business and Management, Vol. 3, No. 2.

Sadewa, P.Y. (2000). The impact of exchange rate on foreign direct investment. Purdue University Press Journal. 
Sandler, T., \& Enders, W. (2008). Economic consequences of terrorism in developed and developing countries. Terrorism, economic development, and political openness, 17.

Shahbaz, Muhammad. "Linkages between inflation, economic growth and terrorism in Pakistan." Economic Modelling 32 (2013): 496-506.

Shaffer, B. (2006). Turkey's energy policies in a tight global energy market. Insight Turkey, 8(2), 97-104.

Simon W.L.S. (1997). "Is There Life Outside the ERM? An Evaluation of the Effects of Sterling's Devaluation on the UK Economy", International Journal of Finance and Economics, 2,199-216.

Srivastava. M. (2016). Syrian refugee entrepreneurs boost Turkey's economy. Financial Times

U.S. Department of State. (1997, August 10). Foreign Terrorist Organizations. Retrieved from the U. S. Department of State website: http://www.state.gov/j/ct/rls/other/des/123085.htm

Waxman, D. (2011). Living with terror, not living in terror: the impact of chronic terrorism on Israeli society. Perspectives on Terrorism, 5(5-6).

Williams, Y. Scatterplot and Correlation: Definition, Example \& Analysis. Retrieved from the Study.com website: http://study.com/academy/lesson/scatter-plot-and-correlation-definitionexample-analysis.html\#transcriptHeader

Yaya, M. E. (2009). Terrorism and tourism: the case of Turkey. Defence and Peace Economics, 20(6), 477-497.

Yuan, L.F. \&Guo, S.J. (2013). The Empirical Research of the Impact of GDP and Exchange Rate on Foreign Exchange Reserve Scale in China-Based on Quantile Regression Model. Research Journal of Applied Sciences, Engineering and Technology. 5(6): 2113-2117, 2013. 